\title{
Community Empowerment In Establishing Entrepreneurial Behavior (Case Study At Pkbm Bina Mandiri Cimahi City And Pkbm Bina Warga Bandung District)
}

\author{
Syaban Apandi ${ }^{*}$, Iim Wasliman ${ }^{2}$, Hanafiah $^{3}$, Helmawati ${ }^{4}$ \\ 1,2,3,4 Universitas Islam Nusantara, Jawa Barat Indonesia \\ ${ }^{*}$ Corresponding author: \\ Email: busssyaban@gmail.com
}

\begin{abstract}
This research is generally to find out about community empowerment in establishing entrepreneurial behavior in PKBM Bina Mandiri Cipageran, Cimahi City and PKBM Bina Warga Ciparay, Bandung Regency. Specifically, it is to know the stages of community empowerment, including: (1) preparation stage, (2) assessment stage, (3) alternative program planning stage, (4) action plan formulation stage, (5) implementation stage, (6) stage evaluation and monitoring, and (7) the termination stage. The method used is a descriptive method with qualitative data types. Data was collected through observation, interviews, and documentation studies. The results of the study indicate that in general both PKBM have empowered the community as the target community quite effectively, being more empowered, both cognitively, affectively, psychomotorically and independently with their entrepreneurial behavior. Specifically, the stages of empowerment are in accordance with the stages, including: (1) preparations carried out by preparing officers and field preparations; (2) assessment, namely by identifying the problems of the target community that have the potential to become learning citizens; (3) planning alternative programs, namely facilitating learning residents in determining the right choice of learning programs to overcome problems; (4) formulation of action plans, namely by determining learning times, recruiting target communities, providing program information; (5) implementation, namely program implementation, which begins with socialization, implementation, identification of results, supporting and inhibiting factors, their contribution to the formation of entrepreneurial behavior and their impact on increasing income and welfare; (6) evaluation, through program evaluation and monitoring; and (7) termination or continuation of the program, namely by providing guidance and assistance to learning residents who have completed the Business Study Group program. These stages have been carried out by the two PKBMs in the implementation of learning programs and community empowerment in shaping entrepreneurial behavior.
\end{abstract}

Keywords: Community Empowerment, PKBM, Entrepreneurial Behavior

\section{INTRODUCTION}

The problems of poverty, unemployment, and low economy are phenomena and problems that have always been a central issue in Indonesian society's life, both in rural and urban areas. Poverty is a condition that describes an imbalance between needs and efforts to fulfil them, so that difficulties and deficiencies arise in various aspects of life that cause a decrease in the quality of human life. These problems arise because of the low level of the economy and limited job opportunities. Based on data from the Central Statistics Agency (BPS), the poverty rate in the first semester (March) of 2019 reached a percentage of $9.41 \%$ or equivalent to 25.14 million people. Interestingly, this figure has decreased by $0.41 \%$ from the same semester in 2018 . Even though it has decreased, the figure is still fairly high.Lack of education level, low quality of human resources, and weak skills (ability) to produce goods and services to entrepreneurial activities are factors cause the weak economy and poverty that occurs. High poverty rates can also occur due to high unemployment rates. According to the BPS, the Open Unemployment Rate (TPT) in February 2019 was recorded at 5.01 percent of the Indonesian workforce participation rate. Based on these results, it is not surprising that the population of the age group over the age of 18 who live below the poverty line reaches $8.77 \%$.

Improvements in the quality and growth of the workforce that are not matched by opportunities or employment tend to make the number of job opportunities decrease. "The reality of unemployment and the low level of the economy is caused by various variables, both endogenous and exogenous variables". (Mulyono, 2012).According to Suharto (2017), "there are at least four categories of poverty that exist in Indonesian society, namely: absolute poverty, relative poverty, cultural poverty, and structural poverty". From a structural perspective, the poverty suffered by a group of Indonesian society is due to the weak 
existing social structure, so that they cannot participate in using the sources of income that are actually available to them. The Indonesian government has implemented various policies and programs aimed at reducing poverty levels and improving the economy, ranging from subsidies, capital loans (KUR), training programs, to programs related to empowering the lower and middle classes. Other efforts are also carried out by organizing community entrepreneurship education programs independently, such as Business Learning Groups, Family Empowerment Post Groups (Posdaya), Joint Business Groups (KUBe), Community Entrepreneurship Education (KUM) programs, PNPM Programs, Productive Village Programs and Joint Groups, Farmers (Gapoktan) and the Family Hope Program (PKH). The government not only issues strategic policies, it also pays attention to various fields, including: social, economic, cultural, political and educational.

Education is one of the main focuses of the government in the national development agenda. Education has a very important role in building the basic physical, spiritual, mental framework that establishes individual character and personality to be independent. The low quality of education and the unequal distribution of educational development are phenomena in the world of Indonesian education. Whereas the fulfilment of good and quality education is a fundamental thing in nation building.In the development of a nation, the existence of Human Resources (HR) plays an important role and becomes the main factor, because the availability of human resources who have adequate capabilities and qualifications will increase the dignity of the nation. To prepare qualified human resources, one of them can be prepared through the educational process. This is very reasonable, because education is a process of humanizing humans in the sense of actualizing all the potential possessed by individuals to have abilities that can be utilized in everyday life in the wider community. Efforts to provide educational services can be pursued through several educational channels, as stated in Law Number 20 of 2003 concerning the National Education System, namely Formal Education, Non-formal Education, and Informal Education which can complement each other (Chapter VI, article 13).

The three types of education function to develop capabilities and build character and civilization of a dignified nation in the intellectual life of the nation. Further explanation in Article 4 paragraph (3) explains that education is held as a process of civilizing and empowering learners that lasts a lifetime; and paragraph (4) that education is held by setting an example, building the will, and developing the creativity of students in the learning process; and paragraph (6), that education is held by empowering all components of society through participation in the implementation and control of the quality of education services. Article 5 paragraph (2) states that every citizen has the right to have opportunity to improve lifelong education and emphasized in Article 13, that the education pathway consists of formal, non-formal and informal education. The functions and objectives of non-formal education are affirmed in PP No. 17 of 2010 Article 102:

1. Non-formal education functions:

a. as a substitute, addition to, and/or complement to formal education or as an alternative education; and

b. develop the potential of students with an emphasis on mastery of knowledge and functional skills, as well as the development of professional attitudes and personalities in order to support lifelong education.

2. Non-formal education aims to form people who have life skills, functional skills, professional attitudes and personalities, and develop an independent entrepreneurial spirit, as well as competence to work in certain fields, and/or continue education to a higher level in order to actualize national educational goals.

3. Non-formal education is held based on the principle of, by, and for the community.

Kindervatter (in Kamil, 2011: 54), argues that: Non-formal education provides a clear role in the empowerment process (empowering process), the role of non-formal education does not only change individuals, but also groups, organizations, and communities which includes improvement and change human resources which is able to build society and the environment. Non-formal education as an empowerment process has a broad meaning, which includes increasing knowledge, attitudes, skills and developing other abilities towards independent living. In the context of non-formal education, independence is the main benchmark in any development of community empowerment programs, so that non-formal education learning programs more specifically have basic competencies that refer to developing the values of 
independence for each target student. Independent behavior is the basis for someone in improving the quality of work that leads to an entrepreneurial attitude. (Kamil, 2011: 93). The Community Learning Activity Center (PKBM) is one of the non-formal education units whose existence will continue to be developed as an empowerment-based education. The management of PKBM is carried out based on the principles of, by, and for the community. It means that the implementation of initiatives is expected to grow and develop based on community's initiatives and needs. PKBM as a place for learning and community empowerment has been initiated and socialized by the Directorate General of Educational Education (PLS) of the Ministry of National Education since 1998 as a response to the increasing number of children dropping out of school and the increasing number of poor people in Indonesia after the economic crisis.In its development, PKBM has faced many obstacles.

According to Kartika (2006), there are several problems related to the implementation of PKBM and require attention from various related parties, especially for PKBM managers, namely: first, the lack of socialization of the existence of PKBM which organizes education and empowerment as well as other programs; second, the slanted view of the surrounding community that considers education in PKBM as a second-class education whose graduate diplomas are merely "diplomas" from the "schools", third, the difficulty of moving to the formal education path for PKBM graduates equivalence (especially packages A, B), due to lack of socialization in enforcing existing rules, namely PP No. 73 of 1991 concerning Education Outside of School (article 10 paragraph (2) and article 14 paragraph (2) which states that it is possible for graduates of package A and package B to move to formal school education; fourth, limited facilities and infrastructure that support the implementation of various learning programs and community empowerment in PKBM; fifth, the activities of fostering and empowering Learning Citizens are not optimal yet, so it is not uncommon to find program target communities who have not completed learning yet are equipped with skills. Skills provisioning is intended so that Learning Citizens have the ability to become entrepreneurs so they are able to be independent in their lives; Learning Citizens who are members of the Business Learning Group (KBU) do not have a business yet or already have, but their business activities cannot be managed properly, even the financial support from the government is not fully available yet; and seventh, there is no follow-up program by the government, either central or local.

Area, also from the program organizers are part of the problem in the implementation of PKBM. This condition will have an impact on the ability of Learning Citizens to maintain their post-graduate abilities and learning outcomes, both learning that is increasing knowledge such as equality and literacy programs or vocational (skills) which will also have an impact on decreasing the ability of Human Resources both locally and nationally. Community empowerment through PKBM is expected to produce quality Learning Citizens who have the ability to be independent, and have the ability to become entrepreneurs.PKBM Bina Mandiri Cipageran, Cimahi City and PKBM Bina Warga Ciparay, Bandung Regency, are PKBM organizers of various community empowerment programs. Based on the results of a preliminary study to the administrators and tutors of the two PKBMs, preliminary information was obtained that the establishment of PKBM originated from the concerns of its founders and that the learning tutor saw the condition of the surrounding community who neglected education due to the demands of economic limitations, resulting in high unemployment and dropout rates. Initial information was obtained that one of the causes of the high rate of not attending school, including drop outs and unemployment in the target areas of the two PKBMs, was because they did not have the money to pay for formal education and other reasons, such as the assumption that schools did not need to be high-level if at the end you go to the kitchen, fields, or to the farms too.

Based on the preliminary study, preliminary information and data were also obtained that most of the population in the two PKBM generally make a living as carpenters, agricultural laborers, and businesses in the informal sector. The presence of PKBM is expected to improve the quality of human resources by providing various learning and skill programs for community members as the target community.A more complete description of the condition of the residents in the target areas of the two PKBMs, among others, as expressed by the Head of PKBM Bina Mandiri Cimahi City Aan Anasih Nawakarana, M.Pd., through interviews, that came from concerns about the high dropout rate in Cipageran both at the elementary, SMP, 
SMA or not continuing school to formal school which will also have an impact on the level of knowledge, attitudes and behavior as well as limited skills. Coupled with high unemployment, this motivated him to form PKBM as a center for learning and empowering the community, especially the Cipageran community in the North Cimahi Region, Cimahi City The description of the condition of the area was also expressed by the Head of PKBM Bina Warga Ciparay, Bandung Regency, Solihin, S.Pd., M.Pd. that currently of the total 16,135 people, 1,364 people have not or dropped out of school, 1,136 people haven't attended school, 129 people are in Kindergarten, 3,908 people are elementary school, 4,960 people are junior high school, 3,869 people are senior high school, 469 people are colle. The data also shows that the dropout rate and unemployment are quite high, so the presence of PKBM in the region is expected to help solve the problems of education and unemployment, especially around the Ciparay Subdistrict, Bandung Regency, especially the graduates can be absorbed by the business world and the industrial world.Along with its development, the two PKBM have organized various learning and community empowerment programs, namely the Equality Education Program (packages A, B, C), Literacy Program (basic, functional, self-employed literacy), Early Childhood Education (PAUD) and Program Business Learning Group (KBU).

The KBU program includes skills in making palm fibre brooms, making knitted beds, sewing, beauty make-up, flower arrangement, ornamental plant (gardening), making red bricks and making snacks, such as making rangginang, making soap made from the basis of cow's milk, making salted eggs, making brownies, and providing knowledge and entrepreneurial skills, which were attended by youth from Karang Taruna and local residents. The role of KBU in the two PKBM in community empowerment is very important and strategic with the consideration that the success of the KBU program is expected to be able to increase the capacity of the poor, unemployed and/or dropouts through entrepreneurship skills. Entrepreneurship skills are expected to encourage economic improvement, and indirectly also have an impact on reducing the dropout rate for economic reasons and spurring more job opportunities for unemployed residents in the two PKBM areas.

The existence of an Entrepreneurship program through KBU in PKBM whose management is carried out by paying attention to sources from local potential, and economically can be developed and supports local economic development, it is hoped that later learning residents can have, manage and develop the business skills they have acquired, both in the form of Productive Economic Business Groups (KUEP), Joint Business Groups (KUBe), small industries, and individual businesses in the informal sector.Based on the results of the preliminary study in the two PKBMs, that in the implementation of Business Learning Groups as an effort to build entrepreneurial behavior for learning citizens, they still face various obstacles, including: first, KBU services have not reached the entire target community yet; second, some community members are still not familiar with the programs organized by PKBM, especially KBU or other life skills and entrepreneurship programs; third, public interest in vocational programs (skills) in PKBM is still lacking; fourth, there are difficulties in marketing skills products, so that KBUs are less developed; fifth, there is no partnership with local entrepreneurs or companies; sixth, lack of support from local community leaders and local institutions; seventh, after acquiring the skills, the learning community has not been able to open their own business, eighth, the network with the business world and the industrial world has not been well established.There are several previous studies that provide an overview of community empowerment activities through PKBM, including:

First, the research conducted by Prihatin, (2016), "Model of Learning Development on Life Skills Education Program for Rural Communities". International Journal of Information and Education Technology, Vol. 6, No. 6, June 2016. The problem behind this research is the lack of PKBM management in the regions. This can be seen from the management side, the availability of facilities and infrastructure as well as supporting resources for PKBM management. From this research, it is known that a very important problem, especially in the PKBM organization, is that the management of PKBM has a difference between expectations and reality which is in line with the rapid number of PKBM, but it is not followed by the increasing number of people who are served and have not made achievements, especially having an entrepreneurial spirit to be able to independent and have an impact on improving the quality of life. 
Second, research conducted by Suminar (2007), "The Relationship between Managerial Ability, Work Motivation and Managers' Perceptions of Community Empowerment Programs with PKBM Service Quality in Garut Regency". Scientific Journal of PNF PTK Vision. Vol. 2. No. 1 2007. The problem in this research is that the quality of PKBM is still low, especially those related to the services provided by PKBM to the community. The growth of PKBM is still quantitative, not accompanied yet by quality. The low quality of PKBM management is caused by three things, namely: the quality of the input, the quality of the process and the quality of the output which have an impact on the suboptimal independence and quality of life of the community as the target community.

Third, the research conducted by Komar (2004), "Model of Small Business Unit-Based Business Learning Group Development in PKBM". Journal of Sociohumanities, Vol. 6, No. 2, July 2004. Described the problem from the results of his research, which the implementation of the entrepreneurship program through the Business Learning Group organized by PKBM did not go through a complete procedure, which was not based on the results of the identification of problems and learning needs of learning citizens, but rather on the judgment of the organizers and managers. Learning residents tend to be placed as laborers/employees, or learning residents are only given funds to run a business. In such conditions, it is necessary to increase understanding for PKBM managers in organizing Business Learning Groups as an effort to improve the entrepreneurial abilities of learning citizens.

Based on the description above, the existence and sustainability of PKBM in community empowerment needs to be organized and developed, especially with regard to entrepreneurship training for learning citizens for entrepreneurial independence through community empowerment studies in PKBM in establishing entrepreneurial behavior.

\section{METHODS}

This study uses a qualitative approach to the type of case study. Technical data collection through interviews, observation, and documentation. The steps of data collection are through the orientation, exploration, and member check stages. The steps of data analysis are through the stages of data collection, data reduction, data presentation, drawing conclusions and verification. The data validity technique was carried out through reliability, dependability, transferability, and confirmability.

\section{RESULTS AND DISCUSSION}

The following will present the discussion that has been revealed in the description of the field findings with a focus on Community Empowerment in Establishing Entrepreneurial Behavior. The discussion in this study will describe the extent to which the stages of community empowerment carried out by the two PKBMs in shaping entrepreneurial behavior.Based on the stages of the community empowerment program developed by Adi (2013: 56), that: The community empowerment stage includes 7 (seven) stages starting with the preparation stage (engagement), assessment (assessment), alternative program planning (designing), formulation of action plans ( formulation), program or activity implementation (implementation), evaluation and monitoring (evaluation), and ends with the termination stage.

This can be described based on the discussion of field findings as follows

\section{Preparation Stage (Engagement)}

The first stage carried out in community empowerment is the preparation stage (engagement), which consists of the preparation of officers and field preparation, Adi (2013: 245), expressed his opinion as follows:

Officer preparation, is the preparation of community empowerment personnel that can be carried out by community workers. This stage is especially needed to equalize the perception among members of the change agent team regarding what approach will be chosen in carrying out community empowerment. The preparation of officers is more necessary if the community empowerment program to be implemented has officers with different educational backgrounds. Field preparation is a prerequisite for the success of a community empowerment program which is basically attempted to be carried out in a non-directive manner. Empowerment activities that took place in the two PKBM included: preparation of officers, namely facilitators or tutors and field preparation, which was the first stage to be carried out. The stages of staff 
preparation carried out by the two PKBM are by exploring the competence of tutors based on their latest expertise and education. The next stage is the stage of field preparation by observing and establishing relationships. Relationships were established with various parties who felt they could be an important part of program implementation, including stakeholders in the implementation of empowerment programs in both PKBM, namely local government, such as kelurahan and RW and RT administrators, local community leaders, and the target community itself who later become citizens of learning.After that, a preliminary meeting was started to get an initial identification of the problems and needs of the residents, especially in the field of business study group learning, that there were still dropout rates in the surrounding community and high unemployment rates. From the results of the initial identification, then the two PKBM parties again held a follow-up informal meeting with local community leaders to discuss the appropriate learning program in overcoming various problems and needs of citizens that were important and urgent to be implemented immediately. The preparation stage carried out by PKBM Bina Mandiri and PKBM Bina Warga, starting from establishing relationships and conducting preliminary meetings with local community leaders, has been in accordance with what Adi said, because at this preparation stage, field preparation stages have been carried out.In the preparation stage, the involvement of the target community is very small.

The learning community is intentionally not included at this stage as a whole with consideration that the learning community is the target of the empowerment program, so there is no need to be fully involved at this stage. The stages of relationship building and informal meeting activities that are carried out are the initial basis in identifying the problems of the target community where the community, in this case represented by local community leaders and several residents, can discuss with PKBM administrators to see the general condition of the community. Relationship building is also carried out as an effort to provide various information needed in the implementation of learning and empowerment programs in business learning groups that will be implemented in both PKBM. The role and involvement of the community at this stage, although not optimal, is still a natural thing considering that the target community does not have full awareness of the needs yet and problems being faced. For this reason, the readiness of the management of the two PKBM in taking over several things at the preparation stage is a logical consequence that can be taken. Local community leaders who are "representatives" of the target community are expected to be relied upon to channel the aspirations and needs of the residents, so that this preparation stage is still within the norm of fairness. In general, the preparation stages carried out by the two PKBM were in accordance with the preparation stages proposed by Adi, especially at the field preparation stage.

\section{Stage of Assessment (Assessment)}

The assessment stage is the stage where there is identification of problems carried out by officers as agents of change. According to Adi (2013: 247), that:

The assessment phase can be carried out individually through community leaders by conducting individual assessments using the focus group discussion method, brainstorming, or the nominal group process. At this stage, the officer as a change agent tries to identify the problem of felt needs and also the resources owned by the client. At the assessment stage, the community has been actively involved so that they can feel that the problems being discussed are the real problems that come out of their own eyes.

The assessment stage has actually been carried out by the PKBM during the preparation stage which began in the form of relationship building activities and preliminary meetings with the target community. The activity of the assessment stage is to identify the problems of the target community. The problem identification activity of the target community is carried out through a process of searching for data on the condition of the population living around the PKBM, with the aim that there is a clear picture of the actual condition of the problems that are currently occurring. This data search process is carried out in two ways, namely through collaboration with the kelurahan, and also through the RW and RT environments to directly collect data and at the same time get a more definite picture of the current conditions in the target community. This process is carried out by holding meetings, and from the results of these meetings, it turns out that it is still difficult for learning residents to find the problems they are facing and when determining their own needs. 
This was due to their lack of participation in the meeting, but in the end local community leaders "took over" the role of the target community by conveying the complaints and needs felt by the residents of the target community. During the meeting, PKBM offered alternative learning programs that were appropriate to be implemented in the context of empowerment, namely programs that could solve the problem of the large number of dropouts, illiteracy, and unemployment. One of the programs that is superior and according to the needs of the target community is the life skills program or Business Learning Group. The PKBM management at this stage acts as a change agent trying to identify problems and also the resources owned by the client. At this stage the community has been actively involved to feel that the problems being discussed are real problems that come out of their own eyes. With a preliminary meeting involving residents, identifying existing problems and identifying the needs of the learning program to be implemented can be more effective because later the program will be more in line with the needs and interests of the residents. This is in accordance with what Galbraith (in Zubaedi: 2016) said, that: community-based education could be defined as an educational process by which individuals (in this case adults) become more competent in their skills, attitudes, and concepts in an effort to live in and gain more control over local aspects of their communities through democratic participation. Community-based education (PKBM) can be interpreted as an educational process in which individuals or adults become more competent in their skills, attitudes, and concepts in an effort to live and control local aspects of their society through democratic participation.

In the activities of the assessment phase, all community members have the right and responsibility to be involved in determining their own needs. In addition, residents also feel that they play an active role and are involved with the PKBM program, which has an impact on a deeper sense of belonging between learning residents and the learning programs in PKBM that they participate in. Based on the assessment stage carried out by PKBM, it can be seen that officers (PKBM administrators) assisted by local community leaders have acted as facilitators by providing opportunities for the target community to find existing problems along with program priorities to be implemented. That way the officers do not impose their views on the community, but it is the community who explore their potential and needs in identifying existing problems. The assessment stage carried out by the two PKBM is also in accordance with the awareness stage, Sulistiyani (in Miradj, 2014), the awareness stage and behavior formation, is a preparation stage in the community empowerment process. This stage emphasizes more on the touch of awareness which will open up more people's desires and awareness about their living conditions. The stage of the process of transforming knowledge and skills can take place well, full of enthusiasm and run effectively if the first stage has been properly conditioned; The stage of enrichment or improvement of intellectual and skill skills needed so that they can form independence.

\section{Stage of Alternative Program Planning (Designing)}

This stage is the stage where there are activities that involve the target community to be more participatory and think about the problems they face and how to overcome them. According to Adi (2013: 249), that: Officers as agents of change in a participatory manner try to involve citizens to think about the problems they face and how to overcome them. The community is expected to be able to think of several alternative programs and activities that they can do. Officers act as facilitators who help the community think about what programs and activities are appropriate at that time. Furthermore, the officers helped to formulate their ideas in written form. At this stage, it is hoped that the officers and the community will be able to imagine and write down what short-term goals they will achieve and how to achieve these goals. So that later it can be directed according to what has been formulated.At this stage, the officers act more as facilitators who help the community discuss and think about what programs and activities are appropriate at that time. In addition, officers and the target community, namely the prospective learning community, can already imagine and write down what short-term goals they will achieve and how to achieve these goals, so that later they can be directed according to what has been formulated.From the findings of the field, at the planning stage of the empowerment program, the administrators in both PKBMs tried to facilitate learning residents to discuss what empowerment program was right about the problems they were facing, namely the problem of the large number of people who were illiterate, dropped out of school and also the high unemployment rate. 
By holding a preliminary meeting, residents can feel that they are participating and involved in planning the empowerment learning program that will be carried out by the two PKBM. Policies in implementing a program do not always have to be carried out with top down planning, but there must also be a demand from the community, so that there is a match between the needs of the community and the empowerment learning program that will be carried out by the two PKBM in order to increase self-capacity. society in determining their future. This is in accordance with what has been stated by Ife (2018), regarding the concept of empowerment, as follows: Empowerment through policies and planning, is carried out by changing existing structures and institutions so that access to appropriate resources occurs, as well as the emergence of community participation. Empowerment emphasizes increasing effective empowerment, where the community can be involved in taking direct actions. Empowerment through education and awareness, emphasizes the importance of the educational process, so that empowered parties acquire the skills to work effectively towards change. The results of the planning stage of this learning program resulted in a decision to try to help learning citizens in overcoming the problems they faced

\section{Action Plan Formulation Stage (Formulation)}

At this stage the PKBM Management takes steps that are a follow-up to the planning, namely determining the timing of the empowerment learning program, recruiting prospective learning citizens, and providing information to the target community. This is in accordance with the stages of formulating the action plan Adi (2013: 250), that "At this stage the change agent helps the target community to formulate and determine the program or activity that is selected or agreed upon from various alternatives with priority considerations".It is known that the timing of the learning program is carried out by means of a meeting or meeting between PKBM management, the result of which is a schedule of activities for the empowerment learning program. In recruiting the target community, the administrators of the two PKBM tried to facilitate the active participation of residents by registering themselves to take part in the required empowerment learning program. PKBM administrators do not force someone to enrol in one particular learning program. In addition, to register for learning program there is also no need to meet various requirements, as long as they have a clear identity, this is useful for collecting data on learning citizens and for making certificates if needed, so that people have the freedom to develop themselves according to their needs and potential owned. This is also because the learning approach carried out in the two PKBM is more of an approach that is in accordance with what is needed by the target community. This is also in accordance with the concept of nonformal education put forward by Coombs (Kamil, 2011: 14), that non-formal education: "is any organized, systematic, educational activity carried on outside the framework of the formal system to provide selected types of learning to particular subgroups in the population, adults as well as children".

Based on Coombs' opinion above, non-formal education is any organized and systematic activity, outside of an established school system, carried out independently or as an important part of a wider activity, which is intentionally carried out to serve the learning of certain students (learning citizens) in a particular context to achieve learning objectives. Likewise at the stage of providing information on learning programs to the community. PKBM management tries to carry out an educational role by conveying information about the learning programs in PKBM and raising public awareness to learn with a wider reach, either directly through word of mouth, or indirectly through posters, pamphlets, and various marketing media. Providing information like this has proven to be effective in delivering learning programs to the community because more and more residents are aware of the programs that will be held by the two PKBM through the means of posters and pamphlets being distributed. By looking at the stages of program planning, recruiting target communities, and providing information on learning programs, it can be concluded that the interactions between the two PKBM administrators have at least increased community participation. The community can easily access existing learning and community empowerment programs without having intervention from PKBM officers or administrators. In addition, learning residents also gain participation in the formulation of learning program planning by being given the opportunity to express their opinions regarding appropriate learning programs that will be implemented as community empowerment programs. 


\section{Implementation Phase (Implementation)}

The implementation stage is the most important stage in the community empowerment program, Adi (2018: 251): The stage (implementation) or program implementation is the most crucial (important) stage in the community empowerment program, because something that has been planned well will be deviated in the process. implementation in the field if there is no cooperation between officers and community members, as well as cooperation between residents.In implementing community empowerment programs, the role of the community as cadres is expected to be able to maintain the sustainability of the programs that have been developed. In addition, in the implementation of this program, the technology used often has to be adapted to the conditions of the community. This is also said by Sihombing (in Kamil, 2011: 85), regarding the concept of community-based education such as the Community Learning Activity Center or PKBM, that: PKBM is a center (centra) and a forum for all community learning activities in order to improve community learning activities. knowledge, skills, hobbies, or talents organized or managed by, from, and for the community, as a forum to prepare community members to be more independent in meeting their needs, including in terms of increasing their income, and as an effort to empower the community more.From the results of the field findings, the implementation phase can be seen in the time used for the Business Learning Group learning program carried out by the two PKBM.

Regarding the timing of the implementation of the Business Learning Group learning program as a community empowerment activity, officers (tutors, technical resource persons) try to make learning citizens able to take part in learning programs at any time that is adjusted to their free time or when they are working or entrepreneurship. Determining the timing of learning activities for Business Learning Groups is not made just like that, but by involving the learning community in determining the learning schedule. This is because the busyness of each learning community is different which then needs to be made an alternative so that all learning residents can participate in KBU learning activities without having to interfere with their busy lives at work or their place of business. Adjustment of study time with work/business schedules, is expected to make learning residents have more opportunities to participate in learning activities at KBU.This is also in accordance with the objectives of non-formal education, in this case PKBM, as stated by Sudjana (in Lutfiansah, 2010), that: the purpose of non-formal education is to develop knowledge, attitudes and skills as well as values that allow for individuals or groups to become efficient and effective learners in the family, work and community environment as well as the environment of the country.In the teaching-learning process of the KBU program, the main thing done by PKBM is to create a comfortable atmosphere for learning residents when carrying out learning activities. Learning is carried out more in the nature of sharing and discussion in the hope of creating a conducive situation for learning residents, thus making learning residents feel more comfortable and able to concentrate more on learning activities at KBU. This is in accordance with what was stated by Simanjuntak (2013: 31), that "PKBM as a learning center should be able to hold educational programs that are in accordance with the learning needs of the educational conditions of the target community".

The implementation of teaching and learning methods carried out in the two PKBM is essentially in accordance with the implementation stage of learning programs in community empowerment activities. In addition, the form of the PKBM implementation stage can also be included in the capacity stage as stated by Wrihatnolo and Dwidjowijoto (2007:101), that: At the capacity-building stage in community empowerment, it is an effort to enable underprivileged communities to have the skills to take the opportunities provided by conduct trainings, and activities that aim to improve life skills". This is indicated by the existence of learning programs that prioritize the capacity for developing skills and abilities for entrepreneurship.Tutors or technical resource persons in the learning process of Business Learning Groups are people who directly communicate with Learning Citizens, therefore many joys and sorrows are faced in the learning process and outside the learning process. In the learning process, the tutor is a manager who includes planning, organizing, leading and evaluating the results of the teaching and learning activities. Tutors in business learning group learning in both PKBM have played a role and carried out their duties well, especially in the learning process, starting from the learning planning stage, learning implementation and evaluating learning outcomes. Conditions like this are in line with the task of educators in learning: (a) Planning, namely setting 
teaching and learning objectives, (b) Organizing, namely connecting or combining all teaching and learning resources in achieving goals effectively and efficiently, (c) Leading, namely motivating citizens learn to be ready to receive the subject matter, and, (d) Supervise, namely whether teaching and learning activities at KBU achieve the goal or not. It is hoped that if the tutor in the learning process of the study group attempts to carry out these four tasks, it will result in a pleasant learning process.

The success of the tasks faced by tutors in teaching and learning activities is influenced by two factors, namely internal factors and external factors. These two factors in the implementation of group in learning business of the two PKBM can be seen from the stage of determining the type of business of the Learning Community where the supporting factors include: (a) the interest of the Learning Citizens to try quite well, (b) the Learning Citizens from participants who come from the functional literacy program has been fluent in reading, writing and arithmetic activities, (c) there are Learning Citizens who already have businesses, (d) there is support from the family environment and natural potential. These four factors provide fluency for tutors in carrying out their duties and functions so that the achievement of Learning Citizens' competence can be achieved.In the implementation stage of learning the skills of the business study group, the role of the tutor is more focused on directing the Learning Citizens to be able to carry out business activities or an increase in business income. From the research findings, it is known that the supporting factors in the implementation of skills learning are the tutor's experience in certified training activities, the guidance from the PKBM head, and the presence of business partners around the study group. The thing that has the most dominant influence on the success in implementing group business skills learning is the tutor's experience in entrepreneurship training activities, especially for technical resource persons who really master certain skills in entrepreneurship.

All the experience gained during the training will be directly applied by the tutor, but if there are problems, expected to ask for help from the PNFI Inspector or Tutor Learning when carrying out coaching and monitoring.With these supporting factors, tutors can further encourage and maximize the business potential of the Learning Community. In addition to the tutor's experience, the driving force is the desire and motivation in the Learning Citizens, although in carrying out the business they have experienced losses and obstacles, but the Learning Community never give up, means that the entrepreneurial spirit in them is embedded, namely: (a) The ability to take risk and make decisions; (b) Having bright and optimistic ideas in trying to think of, developing new, unique ideas and attracting many people, so that they are constantly thinking about innovating; (c) Thorough, diligent and productive; (d) Work in a spirit of togetherness and sound business ethics; (e) Have the motivation to work independently in the sense of not being too dependent on others. The five characteristics of the entrepreneurial spirit, the most important of which is the motivation to work, even though there is sufficient financial support, continuous coaching, but if the Learning Citizens do not have the motivation to try, the result will definitely be a failure. This requires the creativity of tutors in the learning process and must be good at growing and instilling motivation in the Learning Citizens.

There are several techniques to motivate Learning Citizens that can be carried out by tutors, including: (a) Invitation Techniques (persuasive), namely motivational techniques carried out by explaining or inviting Learning People to want to follow our wishes; (b) Stimulation Technique, which is a technique that is carried out by providing stimulation to Learning Citizens with certain rewards, for example by giving gifts, bonuses, awards for Learning Citizens who successfully complete their tasks well so that they are interested and want to increase their interest in learning; (c) Water Ripple Technique, which is a technique carried out by explaining or conveying messages using targets or through community leaders. The tutor as a motivator conveys a message about the importance of holding learning activities for the community. Furthermore, the community leaders are asked to disseminate to the target group, in this case it is necessary to pay attention to language and expressions that are easily understood by the target; (d) Strategic Place Techniques, namely motivational techniques carried out by choosing certain places or activities that are considered strategic, such as village halls, markets, health centers, and so on; (e) Anjangsana Technique, which is a technique carried out by visiting and visiting the target group's house to explain, discuss or ask questions about the material or theme that the target group needs to know/implement to support the goals that have been set; (f) Workplace Visit Technique, is a motivational technique carried out by visiting the https://ijersc.org 
workplace and at the same time helping the work being carried out by the target group to explain, discuss or ask questions about the role that the target group needs to perform; (g) Invitation technique, is a motivational technique carried out by inviting the target group to a place that has been prepared.

In choosing a place to carry out motivation, one should choose a place that is easily accessible by the target group, such as village halls, fields, mosques, buildings, and so on; (h) Media Use Techniques, are motivational techniques that are carried out using written and non-written media which are delivered to the target group. Written media that are often used to motivate Learning Citizens include bulletins, posters, leaflets, and so on. The field results show that the measurement of the success of the Learning Community in increasing business capacity can be seen from several indicators, as follows: (a) The profit or capital obtained by the Learning Community increases; (b) Able to compile business books and control profit and loss; (c) Handle and solve problems and establish partnerships with other learning communities individually or in institutions.In order for all these supporting factors to be well maintained, maintenance is not only the responsibility of the tutor, but all components must be involved. These components are: Tutors, PNFI Supervisors, SKB, Learning Citizens and PKBM Chairpersons. In each stage of implementation, all these components must have their respective duties and roles so that there will be no inequality and build-up of work. Like the PNFI inspectors and the SKB learning tutors, they must be motivators in implementing the program as outlined in monitoring and coaching activities.

This means that coaching in the implementation of the PNFI program has a very important role, because with the guidance program managers will know the problems and find solutions. Coaching is essentially a series of professional control efforts over all elements of the organization so these elements function properly in order to achieve goals that can be carried out, efficient, and effective.In any learning process, apart from supporting factors, there are also inhibiting factors. Likewise, from the results of field findings through interviews and observations in business study groups, it can be seen the inhibiting factors both internally and externally. Internally, the obstacles that hinder tutors from increasing the learning community's entrepreneurship are the lack of tutors' ability in both PKBM in making media or images relevant to the learning topic, too many expectations of learning residents to make media and learn materials to support the skills they want and the lack of funds for doubling the material. As we understand, that learning media is a tool to clarify the material presented, therefore for Learning Citizens business study groups whose participants are from different backgrounds, this media will strengthen the power of reasoning and memory of the discussion they are participating in. But for a tutor, don't give up even though in reality they can't make relevant media, but the media can be made in a simple way which is important to attract and clarify in achieving learning objectives.Externally, the inhibiting factor is the lack of guidance from PNFI Supervisors, so the problems faced internally have not been optimally resolved.

The time for the guidance from the PNFI inspectors is uncertain, but the tutors proactively ask for help from other parties, such as the PKBM chairperson and the UPT SKB Tutor of Learning. Ideally, coaching is carried out at least once a month, namely directly to solve all problems encountered in business study group learning. Another problem is that the available working capital is not commensurate with the business needs of the Learning Citizens, this can be seen where every Learning Community has business expectations that require quite large costs, so adjustments are needed to the type of business being developed. Based on the observation of the reality on the ground, it turns out that the learning community's interest in the business is quite enthusiastic, but the conditions have not been matched by an understanding of business risks, so there are still many learning residents who experience losses. Even though there are always losses in business activities, the Learning Citizens do not feel deterred, even they are still enthusiastic to maintain their business and there are also those who add other businesses. This condition is one of the forerunners to the growth of the entrepreneurial spirit in the Learning Citizens. The many failures and problems faced by Learning Citizens in their business activities will enrich the learning community's thinking to find solutions to business activities that are being or will be developed. Experience is the best teacher, so armed with experience, whether it is positive or negative, a person will be more careful in carrying out every step of the business. 
The inhibiting factor felt by the tutor in maintaining the learning community's business was the presence of business competitors in the learning community, both sellers of similar and different goods. Besides the existence of competitors, based on the analysis of the interviews and observations results, it turns out that Learning Community lacks the courage to make business breakthroughs or enter into partnerships, whereas with partnership activities there will be several benefits, including: (a) Adding a network for product marketing; (b) Obtain NST in accordance with the developed business field; (c) Open access to find out the availability of funds and facilities that support business activities; (d) Covering the weaknesses encountered during the business and learning process. On the other hand, the inhibiting factor faced by tutors is the cultural attachment to the Learning Citizens that whatever capital they have received so far must be spent to meet business needs. From this attitude, it shows that the Learning Citizens do not have a thorough plan in business development, even during the business process they are still less painstaking in recording or bookkeeping.

\section{Stage of Evaluation and Monitoring (Evaluation)}

A good evaluation in an empowerment process is an evaluation that involves the community, so it is hoped that later a process of control and feedback can be realized from the community who directly experience the program. In the evaluation, there are three forms of evaluation, namely through evaluation meetings between administrators and tutors, informal evaluations with learning residents, and evaluation by making accountability reports for programs that have donors or sponsors. Based on field findings, although there has been an evaluation process, it was all done internally by the management without involving the residents to find out the results of the evaluation that had been carried out. Meanwhile, an informal evaluation with learning residents has been carried out periodically at the end of learning. The evaluation stage carried out by the two PKBM, when compared to what Adi (2013: 252) stated, that: Evaluation as a process of monitoring from residents and officers on ongoing programs should be carried out involving residents.

Community involvement, it is hoped that a system will be formed to carry out internal supervision. Sometimes the results of monitoring and evaluation are not as expected. If this happens, the process evaluation is expected to provide useful feedback for the improvement of an activity. So that, if necessary an assessment can be carried out on the problems felt by the community.The evaluation carried out by the two PKBM is still far from the process of monitoring learning citizens, only temporary and accountability is also only carried out on programs whose sponsors request activity reports. This will certainly have an unfavourable impact on the implementation of the learning program in the Business Learning Group, because the target community cannot provide criticism or input regarding the learning program that has taken place as a community empowerment program.

\section{Termination or Sustainability Stage}

Adi (2013: 253), argues, that termination is: a formal 'severance' of relations with the target community. Termination in a community empowerment program is carried out not because the community can be considered "independent", but rather because the project has to be stopped because it has exceeded the previously determined time, or because the budget has been completed and there are no funders who can and want to continue. However, officers should stay out of the target community gradually and not suddenly. These needs are done so that the community does not feel left out unilaterally and without preparation. If officers feel that their duties have not been completed properly, it is not uncommon for officers to keep in contact, even though not routinely, and then gradually reduce contact with the target community. The termination stage is a formal 'severing' of relations with the target community, which is often done, not because the community can be considered 'independent', but rather because it has exceeded the predetermined time period.

Based on field findings, the termination stage as stated by Adi has not been seen, this is because PKBM Bina Mandiri and PKBM Bina Warga as a community-based non-formal education unit are still carrying out various learning programs which are a form of community empowerment. In addition, currently the two PKBM are still developing other learning programs, the aim is also to empower their learning citizens. In essence, the empowerment carried out by the two PKBM is carried out as a program where 
empowerment as a process continues for the target group. This termination stage was also not carried out by the two PKBM, because they wanted to measure progress in implementing various community empowerment programs that had been carried out through PKBM parameters. On the parameters of the independence and sustainability of the institution, the ability of PKBM to continue to run well in implementing its programs and continue to run continuously in carrying out all its programs in accordance with the dynamics of the community's needs is the main thing. In other words, until now PKBM Bina Mandiri and PKBM Bina Warga are still carrying out community empowerment activities through their learning programs and have not carried out yet the termination stage.

\section{CONCLUSION}

Based on the results of the study, it is shown that in general PKBM Bina Mandiri Cipageran, Cimahi City and Bina Warga Ciparay, Bandung Regency, has empowered the community, especially learning residents through business learning group programs that have an impact on the target community quite effectively and are increasingly empowered, both cognitively, affectively, psychomotor. and independent with their entrepreneurial behavior. The stages of community empowerment in the two PKBM in establishing the entrepreneurial behavior of learning citizens have been carried out starting from the preparation, assessment, planning, action plan formulation, implementation, evaluation and monitoring stages, to termination..

\section{HYPOTHETICAL MODEL}

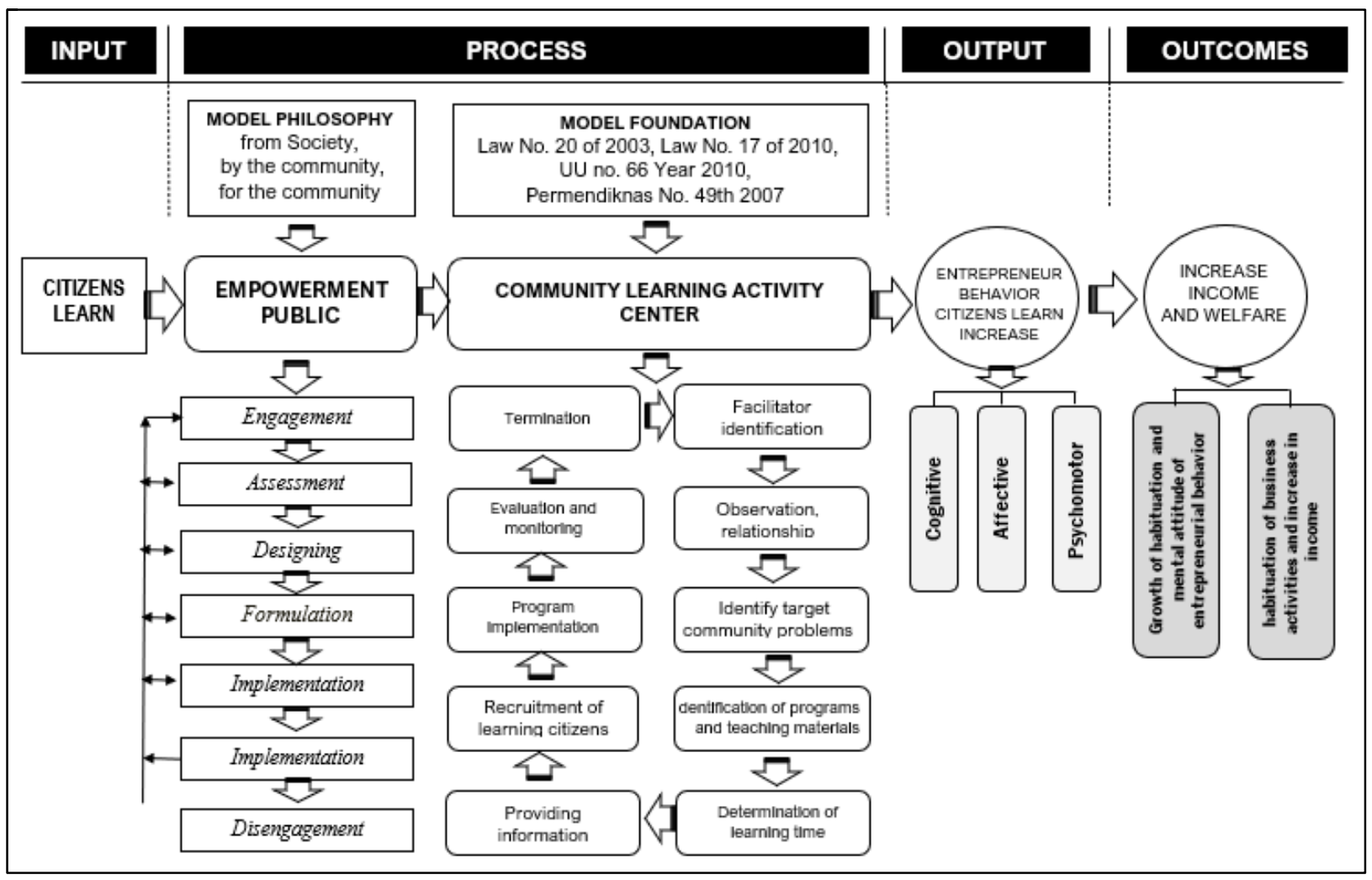

\section{REFERENCES}

[1] Adi, Isbandi Rukminto, (2008), Intervensi Komunitas: Pengembangan Masyarakat Sebagai Upaya Pemberdayaan Masyarakat. Jakarta: Rajagrafindo Persada.

[2] Adi, Isbandi Rukminto, (2002), Pemikiran-pemikiran dalam Pembangunan Kesejahteraan Sosial, Jakarta: Universitas Indonesia.

[3] Alma, B (2005). Kewirausahaan. Bandung : Alfa Beta.

[4] Anwas, Oos, M, (2019), Strategi Menulis Artikel Jurnal Bereputasi, Bandung: Remaja Rosda Karya.

[5] Anwas, Oos, M, (2013), Pemberdayaan Masyarakat di Era Global, Bandung: Alfabeta. 
[6] Arif, .Zaenudin, (2012). Andragogi. Bandung: CV Angkasa. Balap Pengembangan Kegiatan Belajar. (2001) Standar Minimal Pusat Kegiatan Belajar Masyarakat Berbasis Masyarakat. Jakarta: Balai Pengembangan Kegiatan Belajar (BPKB) Jayagiri Kerjasama dengan UNESCO.

[7] Creswell, John, W, (2018), Research Design, Pendekatan Metode Kualitatif, Kuantitatif, dan Campuran, Yogyakarta: Pustaka Pelajar.

[8] Disdik Provinsi Jabar. (2011), Kewirausahaan Untuk Usaha Rumah Tangga. Bandung: Dinas Pendidikan Provinsi Jawa Barat

[9] Kartasasmita, G. (1996). Pemberdayaan Masyarakat : Konsep Pembangunan yang Berakar pada Masyarakat. Yogyakarta : UGM, Tidak diterbitkan.Kemendikbud. (2012). Standar dan Prosedur Penyelenggaraan Pusat Kegiatan Belajar Masyarakat (PKBM). Jakarta: Direktorat Pembinaan Pendidikan Masyarakat, Direktorat Jenderal Pendidikan Anak Usia Dini Non Formal dan Informal, Kementerian Pendidikan dan Kebudayaan.

[10] Ife, Jim. (2016). Community Development: Alternatif Pengembangan Masyarakat di Era Globalisasi. New York: Macmillan Publishing Company.

[11] Hasan, ES., (2007), Strategi Menciptakan Manusia yang Bersumber Daya Unggul,Bandung: Jurusan Pendidikan Luar Sekolah Fakultas Ilmu Pendidikan, UPI.

[12] Hanafi, Abdillah. (1997). Memasyarakatkan Ide-Ide Baru. Surabaya: Usaha Nasional.

[13] Hikmat, R. Harry .(2006). Strategi Pemberdayaan Masyarakat. Edisi Revisi. Bandung: Humanira Utama Press.

[14] Kamil, Mustofa. (2012). Model Pendidikan dan Pelatihan: Konsep dan Aplikasi. Bandung: Alfabeta.

[15] Kamil, Mustofa. (2011). Pendidikan Nonformal: Pengembangan Melalui Pusat Kegiatan

[16] Kemendikbud. (2011). Pedoman Penyelenggaraan dan Pembentukan PKBM. Jakarta: Direktorat Pembinaan DIKMAS Kemendikbud.

[17] Moleong, L J. (2014). Metodologi Penelitian Kualitatif. Bandung: Remaja Rosda Karya.

[18] Mutis, T. (1995). Kewirausahaan yang Berproses. Jakarta: Gramedia Widiasarana Indonesia.

[19] Sanusi, Achmad. (2017), Sistem Nilai, Bandung: Nuansa Cendekia.

[20] Sulistiyani, Ambar Teguh. (2004). Kemitraan dan Model-Model Pemberdayaan. Yogyakarta: Gayamedia.

[21] Sihombing, U. (2001). Pendidikan Luar Sekolah Masalah, Tantangan dan Peluang, Jakarta: Wirakarsa.

[22] Sudjana, D. (2001). Strategi Pembelajaran dalam Pendidikan Luar Sekolah. Bandung: Falah Production.

[23] Sudjana, D. (2004). Pendidikan Non Formal (Wawasan, Sejarah Perkembangan, Filsafat,Teori Pendukung, Asas. Bandung: Falah Production.

[24] Sudjana, D. (2006). Evaluasi Program Pendidikan Luar Sekolah untuk Pengembangan Pendidikan Non Formal dan Pengembangan Sumber Daya. Bandung: PT. Remaja Rosdakarya.

[25] Suharto, E., (2018), Membangun Masyarakat Memberdayakan Masyarakat, Kajian Strategis Pembangunan Kesejahteraan Sosial \& Pekerjaan Sosial, Bandung : PT. Refika Aditama.

[26] Suryana. (2005), Kewirausahaan: Pedoman Praktis, Kiat dan Proses Menuju Sukses, Jakarta: Salemba Empat.

[27] Tilaar, A. (1992). Manajemen Pendidikan Nasional. Bandung: Remaja Rosda Karya.

[28] Trisnamansyah, S. (2009). Metode Penelitian Kuantitatif dan Kualitatif. Bandung: Pasca Sarjana UPI.

[29] Wartanto. (2019). Arah Kebijakan dan Tantangan Inovasi Pendidikan Masyarakat di Era Industri 4.0 Dalam Mencapai Target MDGs 2030. Jakarta: DirektoratJenderal Pendidikan Anak Usia Dini dan Pendidikan Masyarakat Kementerian Pendidikan dan Kebudayaan RI

[30] Dacholfany, M. Ihsan. (2018). Pemberdayaan Masyarakat Dalam Meningkatkan Mutu Pendidikan Non Formal di Metro Lampung (Studi Kasus di PKBM Al-Suroya). Jurnal TAPIS, Vol. 02, No. 1 Januari - Juni 2018. Lampung: Universitas Muhammadiyah Metro.

[31] Haluty, Djaelani. (2014). Islam dan Manajemen Sumber Daya Manusia yang Berkualitas. Jurnal Irfani, Volume. 10 Nomor 1. Gorontalo: Fakultas Ilmu Tarbiyah dan Keguruan UIN Sultan Amai.

[32] Hasan, Engking Swarman. (2012). Pendidikan Luar Sekolah dan Pembangunan Manusia Indonesia. Empowerment: Jurnal Ilmiah Program Pendidikan Luar Sekolah IKIP Siliwangi Vol 1, No. 1. Bandung: Iinstitut Keguruan dan Ilmu Pendidikan Siliwangi.

[33] Heryanto, Nunu. (2009). Pemberdayaan Masyarakat Dalam PAUD Non Formal. Jurnal Pendidikan Luar Sekolah, Vol 4 No 2. Bandung: Departemen Pendidikan Luar Sekolah Fakultas Ilmu Pendidikan UPI.

[34] Hasanudin, Apidin (2005). Dampak Pelaksanaan Program Pelatihan Kecakapan Hidup (Life Skills) Budi daya Tanaman Pisang Dalam Peningkatan Pendapatan Masyarakat Di Desa Sunten Jaya Kec. Lembang Kab. Bandung. Jurnal PLS Vol. 4, No. 2. Bandung: Departemen PLS UPI.

[35] Hiryanto. (2008). Pemberdayaan Masyarakat Melalui Pendidikan Non Formal. Lokakarya Pemberdayaan Masyarakat dalam Pendidikan Luar Sekolah, 22 November 2008. Bantul: Badan Perencanaan Pembangunan Daerah. 
[36] Ibrahim. (2018). Pemberdayaan Masyarakat Melalui PKBM Untuk Meningkatkan Keterampilan Masyarakat Miskin. Jurnal Tamkin UIN SGD Vol 3, No 1, Bandung: Universitas Islam Negeri Sunan Gunung Djati.

[37] Laksono, Adi. (2019). pemberdayaan masyarakat melalui lembaga sosial dan pendidikan. Jurnal Pendidikan Nonformal, No. 14 Vol. 1. Malang: Universitas Negeri Malang.

[38] Lutfiansyah, D. Yunus. (2011). Pendidikan Kecakapan Hidup (life skills) Dalam Pemberdayaan Perempuan Kepala Keluarga (PEKKA) Untuk Peningkatan Pendapatan dan Kemandirian Berwirausaha. Jurnal PLS No. 6, Vol. 7. Bandung:Departemen Pendidikan Luar Sekolah UPI.

[39] Miradj, Safri. (2014). Pemberdayaan Masyarakat Miskin, Melalui Proses Pendidikan Non Formal. Jurnal Pendidikan dan Pemberdayaan Masyarakat, Vol. 1, Nomor 1. Yogyakarta: Universitas Negeri Yogyakarta.

[40] Mulyono, Dino. (2012). Menegakan Karakter Pendidikan Nonformal, Jurnal Empowerment, No. 1 Vol 1. Bandung: IKIP SiliwangiSumiati, Ema. (2016). Model Pemberdayaan Masyarakat Dalam Mempertahankan Kearifan Lokal. Damar: Jurnal Penelitian dan Pengkajian Pendidikan Non Formal, Edisi VIII. Bandung: Pusat Pengembangan Pendidikan Anak Usia Dini dan Pendidikan Masyarakat Reg. Jabar.

[41] Saraswati, Gaharani. (2015). Pemberdayaan Masyarakat Melalui Wirausaha Kreatif Berbasis Kearifan Lokal. Jurnal Penelitian dan Pengkajian Pendidikan Non Formal Damar Jayagiri Edisi VII, 73. Bandung: PPPUDNI Reg. I.

[42] Sofinisa, Aulya. (2015). Pemberdayaan Masyarakat Sebagai Upaya Meningkatkan Ekonomi Pedesaan. Jurnal Administrasim Publik Vol. 3 No. 11. Malang: Jurusan Administrasi Publik, Fakultas Ilmu Administrasi, Universitas Brawijaya.

[43] Syamsi Ibnu. (2010), Pendidikan Luar Sekolah Sebagai Pemberdaya Dalam Masyarakat. DIKLUS: Jurnal Pendidikan Luar Sekolah Vol. 14, No. 1. Yogyakarta: Jurusan Pendidikan Luar Sekolah Fakultas Ilmu Pendidikan UNY.

[44] Susanti, Santi.(2014).Meningkatkan Efektivitas Pendidikan Nonformal dalam Pengembangan Kualitas Sumber Daya Manusia, Jurnal Handayani Vol 1 No. 2. Medan: Fakultas Ilmu Pendidikan Universitas Negeri Medan..

[45] Sudarsana, I Ketut. (2018). Peningkatan Mutu Pendidikan Luar Sekolah Dalam Upaya Pembangunan Sumber Daya Manusia. Jurnal Penjaminan Mutu Vol. 4, Edisi 1. Denpasar: Institut Hindu Dharma.

[46] Tohani. (2011). Pendidikan Non Formal dan Pengurangan Kemiskinan di Pedesaan, Jurnal Walisongo Vol. 19, No. 2. Yogyakarta: Universitas Negeri Yogyakarta

[47] Wasitohadi. (2014). Hakekat Pendidikan Dalam Perspektif John Dewey. Jurnal Satya Widya, Vol. 30, No. 1. Salatiga: Program Studi PGSD Universitas Kristen Satya Widya. 